\title{
A HISTÓRIA NA TELEFICÇÃO: ECOS DO JORNAL A VOZ DA RAÇA NA CONSTRUÇÃO DA MEMÓRIA SOCIAL
}

\section{THE HISTORY TELEFICÇÃO: ECHOES THE OFFICIAL VOICE OF THE RACE IN THE CONSTRUCTION OF SOCIAL MEMORY}

Niterói (RJ), v. 35, n. 3

dez/2016-mar/2017

A Revista Contracampo é uma revista eletrônica do Programa de Pós-Graduação em Comunicação da Universidade Federal Fluminense e tem como objetivo contribuir para a reflexão crítica em torno do campo midiático, atuando como espaço de circulação da pesquisa e do pensamento acadêmico.

\section{ROBÉRIA NÁDIA ARAÚJO NASCIMENTO}

Doutora em Educação pela Universidade Federal da Paraíba (2007). Mestre em Ciência da Informação pela Universidade Federal da Paraíba (2001). Professora Titular do curso de Comunicação Social (UEPB), vinculada aos Grupos de Pesquisa Comunicação, Cultura e Desenvolvimento e Comunicação, Memória e Cultura Popular, e à linha Mídia e Estudos Culturais. Brasil.

rnadia@terra.com.br

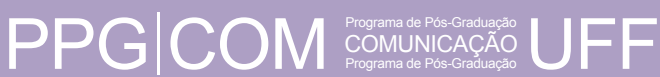

AO CITAR ESTE ARTIGO, UTILIZE A SEGUINTE REFERÊNCIA:

NASCIMENTO, Robéria Nádia Araújo. A história na teleficção: ecos do jornal A Voz da Raça na construção da memória social.

Contracampo, Niterói, v.35, n. 03, dez. 2016/ mar. 2017.

Enviado em: 27 de julho de 2015 / Aceito em: 26 de abril de 2016. 


\section{Resumo}

Este texto deriva de uma pesquisa que analisou a ressonância da ficção televisiva na valorização da religiosidade afro-brasileira e na visibilidade da pessoa negra na minissérie Tenda dos Milagres, inspirada na obra de Jorge Amado. A adaptação televisiva faz referência ao papel social do periódico A Voz da Raça, pertencente à Imprensa Negra, fundado em São Paulo nos anos de 1933. A abordagem busca demonstrar que o gênero ficcional, a partir de reconstituições históricas e dos fragmentos dos diálogos entre os personagens, pode se tornar um relevante espaço de fruição para se pensar as desigualdades raciais, as identidades coletivas (CUCHE, 2002; HALL, 2005) e os preconceitos étnicoreligiosos (GOFFMAN, 1988) contribuindo para a construção da memória social (LE GOFF, 2006; POLLAK, 2000).

\section{Palavras-chave}

Ficção televisiva; memória social; preconceito étnico-religioso

\section{Abstract}

This text comes from a study that examined the resonance of TV fiction in valuing religiosity afro-brazilian and the visibility of the black person in minisserie Tent of Miracles, inspired by the work of Jorge Amado. The television adaptation makes reference to the social role of the journal The Voice of Race, belonging to the Black Press, founded in Sao Paulo in the years to 1933 . The approach seeks to demonstrate that the fictional genre, from historical reconstructions and the fragments of the dialogs between the characters, can become an important area of enjoyment to think racial inequalities, the collective identities (CUCHE, 2002; HALL, 2005) and prejudices ethnic-religious (GOFFMAN, 1988) contributing to the construction of social memory (LE GOFF, 2006; POLLAK, 2000).

\section{Keywords}

TV Fiction; social memory; prejudice ethnic-religious 


\section{Introdução}

Este artigo deriva de uma pesquisa ${ }^{1}$ que analisou os arquétipos místico-religiosos e as contribuições da ficção televisiva para a valorização da religiosidade afro-brasileira e da visibilidade da pessoa negra na minissérie Tenda dos Milagres, baseada no romance homônimo de Jorge Amado, escrito em 1969. Para além da perspectiva do entretenimento, esse produto ficcional nos incita pensar nas condições de desigualdade social do contexto baiano nos anos de 1930. A historicidade dessa conjuntura, que se repetiu no país, foi atravessada pelo combate à miscigenação étnico-cultural e pelo ativismo de denúncia social enquanto mecanismos de superação das expropriações escravocratas, da discriminação de cor e de crença religiosa, causas defendidas pela Imprensa Negra, sobretudo nas páginas do periódico A Voz da Raça, cujos trechos são mencionados na minissérie.

A historiografia brasileira sobre o jornalismo ${ }^{2}$ aponta $A$ Voz da Raça como um dos relevantes veículos produzidos por negros e para negros, em razão de sua longevidade (1933-1937), estrutura e organização político-social, constituindo um eficiente canal por onde circulavam mensagens de liberdade, que ajudaram a escrever a história do movimento negro brasileiro e a imprimir o respeito pela identidade étnica em tempos de preconceitos e estereótipos. Parece-

\footnotetext{
1 Intitulada Os arquétipos místico-religiosos na ficção televisiva: o universo simbólico de Tenda dos Milagres, do Curso de Comunicação Social da UEPB com apoio do CNPq, concluída em 2012, incluindo João Saraiva da Silva Neto e Walquísia Raquelle Freire Gouveia, orientandos de Iniciação Científica. Versões derivadas do estudo foram apresentadas recentemente no I Simpósio Internacional Brasil e Itália, realizado entre 23 e 26 de agosto de 2015, na UEMA, no Maranhão, no Grupo Temático Diversidade Religiosa na Sociedade Secularizada, sob a mediação do Prof. Dr. Reginaldo Prandi. O nome da minissérie se refere à rudimentar tipografia de Lídio Corró (Milton Gonçalves), artesão de madeira, local que funciona como residência e ponto de encontro da boemia baiana. Agrega objetos que representam os milagres dos santos, feitos sob encomenda dos católicos beneficiados pelas graças alcançadas, como também acolhe as máquinas rotativas de impressão dos primeiros folhetos produzidos por Archanjo. Nesse ambiente sincrético entre o sagrado e o profano, o catolicismo e o candomblé, emergem a obstinação e a intelectualidade do protagonista, que se revolta contra as injustiças sociais e elabora os seus escritos, com o apoio da jornalista Ana Mercedes (Tânia Alves). A minissérie possui 30 capítulos e foi dirigida por Aguinaldo Silva e Regina Braga. Hoje, encontra-se reunida num Box de quatro DVDs, lançado pela empresa Globo Marcas.

2 No período colonial, já havia manifestos impressos dos negros. O tipógrafo Francisco de Paula Brito fundou no Rio de Janeiro o jornal "O Homem de Cor", que posteriormente recebeu o nome de "O Mulato", considerado precursor da Imprensa Negra do país. Jornais anteriores à Voz da Raça também exerceram um significativo papel de porta-voz dos direitos dos excluídos no Brasil, ajudando a compor a historiografia do movimento negro. Foram cerca de 30 em São Paulo: os periódicos A Pátria, O Propugnador, A Pérola, O Alfinete, A Liberdade, A Sentinela, O Clarim da Alvorada, Tribuna Negra, que reuniram entre seus colaboradores nomes da literatura e militantes da causa da negritude por justiça social.
} 
nos que a menção a esse periódico na ficção torna-se um registro histórico oportuno para atualizar as questões que perpassam a busca pela cidadania negra.

O periódico tinha formato tabloide, cujo conteúdo era distribuído em quatro páginas, preenchidas com artigos, notícias, notas, chamadas, informes, tendo por cabeçalho a frase, atribuída a Isaltino Veiga dos Santos: "O preconceito de cor, no Brasil, só nós, os negros, o podemos sentir". O jornal, fundado por Francisco Costa, integrante da Frente Negra Brasileira (FNB), publicou 70 edições, com periodicidade semanal no início, posteriormente quinzenal, e em 1937, década do seu encerramento, tornou-se um jornal mensal. Como documento oficial da FNB, derivado do seu teor discursivo-político em prol da emancipação da comunidade negra, foi extinto com a instauração do Estado Novo. Mais do que uma finalidade informativa, A Voz da Raça era um canal simbólico de diálogo e reivindicações dos negros, uma vez que seu maior propósito era instigar a superação do conformismo e da passividade dos marginalizados, combatendo o preconceito racial em suas diversas formas e disseminando uma visão positiva da ancestralidade negra. Na página dedicada às "Notícias e Destaques do Passado" eram discutidas questões relevantes sobre etnicidade. Por essas razões, pode ser considerado um instrumento de preservação da memória social brasileira, ao registrar o período histórico pós-abolição.

Sua proposta editorial tinha como palavras de ordem "Deus, Pátria, Raça e Família", homenageando abolicionistas como José do Patrocínio e Luiz Gama, além de figuras míticas, a exemplo de Zumbi, enaltecido por ter criado no Brasil um "Estado Perfeito", numa referência ao Quilombo dos Palmares. Todavia, o jornal era criticado pelos demais movimentos negros por representar linearmente a postura da FNB, comparando seus membros a "apóstolos modernos", e acusado de reproduzir a ideologia frentenegrina, constituindo uma discussão que não nos deteremos aqui.

Tratava-se de uma publicação inovadora para os padrões socioeconômicos da época, pois contava com sistema de assinaturas, 
distribuição para outros estados, impressão terceirizada, apresentando debates com intelectuais externos à comunidade negra, o que significava prestígio social. Suas páginas tinham espaço para arte, cultura, poesias e colunas escritas por mulheres, entre elas a "Rosas Negras". Temas como religiosidade afro-brasileira, samba, capoeira eram abordados como expressões africanas a serem respeitadas no espaço social.

No entanto, a preocupação do jornal com o nacionalismo sobressaia. Numa edição, lia-se: "Em São Paulo, há uma infinidade de negros desempregada. Os lugares são ocupados por estrangeiros. Há patrões e chefes de obras que não contratam operários brasileiros, sobretudo se são negros." (A VOZ DA RAÇA, n. 44, 1934, p.1). A edição seguinte reiterava "o desejo de construir uma identidade negra distinta da branca. A cultura e a história dos negros devem reerguer sua moral e contribuir para sua educação." (A VOZ DA RAÇA, n.45, 1934, p.2). Combatia as opiniões racistas e pejorativas manifestadas na imprensa regular, incentivando os negros a agir contra as injustiças.

Vale salientar ainda que atuou também na formação das sociabilidades negras. Correia (2004) explica que essa imprensa, de teor alternativo, surgiu de um jornalismo comunitário, que instiga a união e incorpora desejos e cobranças das esferas públicas locais ou ligadas a movimentos de caráter social. "Esses movimentos particularizam as informações dos periódicos, dando voz às expressões populares que não encontravam espaço na imprensa oficial, delineando suas identidades" (CORREIA, 2004, p. 193).

Conforme argumenta Cuche (2002), a identidade de um indivíduo se vincula a um sistema social, a uma classe, a uma nação, demarcando - lugar de onde o indivíduo fala e se percebe enquanto ser de sensibilidades e racionalidades. A ideia de identidade emerge, portanto, das experiências socialmente compartilhadas e das negociações de sentidos que, no período citado, auxiliaram a delinear o ativismo negro na escritura da história do povo brasileiro, nem sempre tecida pela valorização das diferenças. Nessa perspectiva, o autor defende que a afirmação da identidade legítima de um povo esboça o reconhecimento 
das especificidades culturais na luta contra a hegemonia social. No personagem Pedro Archanjo (Nelson Xavier), temos o exemplo do homem negro que luta pela visibilidade dos seus direitos e de seus costumes socioculturais num contexto em que as diferenças sociais e de crença religiosa são vistas como sinônimos de exclusão. Dessa forma, a narrativa da ficção forja o protagonismo da imprensa para dar vez e voz a indivíduos que não encontravam espaços de expressão na sociedade da época.

Pelos aspectos mencionados, Tenda dos Milagres é considerada uma obra sociológico-literária por representar a fase de engajamento de Jorge Amado às questões socioculturais, entrelaçadas com personagens atuantes nas causas da miscigenação e da cidadania dos negros, mediante o enfrentamento dos poderes e da inferioridade atribuída à negritude. Aborda a religiosidade ancestral, a partir do candomblé, articulando seus hibridismos e sincretismos, disseminando suas práticas nos imaginários populares, enquanto meios de enfrentamento dos preconceitos vividos pelos protagonistas. Na linguagem audiovisual, destacam-se os encontros e desencontros com a fé católica, bem como a perseguição da polícia aos cultos e rituais de matriz africana, notabilizados, sobretudo, nas cenas do terreiro de Majé Bassã (Chica Xavier). Na minissérie, há uma dinâmica de entrelaçamento que faz convergir as culturas, as religiões, os saberes, as raças, a luta pela igualdade social delineando questões que formatam a memória social coletiva.

De acordo com esse raciocínio, o universo da teleficção sugere algumas questões que nos parecem pertinentes: como um produto ficcional pode atuar na construção da memória? De que modo problematiza questões sociais, a exemplo do racismo? A complexidade dessas inquietações permeia este texto que, ao focalizar a narrativa amadiana, busca notabilizar o viés de denúncia das desigualdades e injustiças sociais que compõem os escritos do jornal $A$ Voz da Raça. 
Jorge $A$ mado 3 é o escritor brasileiro mais conhecido no mundo por (re)criar imagens de um país singular e mestiço. Assim, Tenda dos Milagres, que também migrou para a tela do cinema (sob a direção de Nelson Pereira dos Santos, em 1977), é um dos exemplos de fruição mais bem sucedidos da transmutação de uma obra literária para a narrativa televisiva. A dramaturgia amadiana, de caráter atemporal, enfatiza a esperança na cultura popular, denunciando a exclusão social em seus diversos matizes, permitindo, com isso, o debate das interculturalidades, das alteridades humanas e da liberdade de crenças.

A personificação de Pedro Archanjo (cujo nome significa "anjo de ordem superior") reúne uma síntese de qualidades resilientes, ao enfrentar, corajosamente, o seu não saber na busca de fundamentação teórica para se contrapor às teses racistas que vigoravam na sociedade da época, contra-argumentando seu principal opositor o médico, Nilo Argolo (Oswaldo Loureiro). O catedrático da Faculdade de Medicina da Bahia afirmava em seus livros que os mestiços eram "seres indolentes, apáticos, impulsivos - por isso tenderiam ao crime, além de sexualmente perversos". Assim, entre estudos, leituras, rituais de fé e rituais profanos, o carisma e a personalidade solidária de Archanjo o levam a escrever livros, aprender idiomas, até que se torna bedel da Faculdade de Medicina, lugar onde conquista admiradores para a sua luta em prol da cidadania negra. Na minissérie, esse fato é forjado pela tematização místico-religiosa em torno dos poderes do orixá Xangô, que o nomeia "a luz do seu povo", inspirando-o a escrever sobre as injustiças para combatê-las. Desse modo, Jorge Amado fortalece seu herói permeando-o com as fraquezas e desafios humanos, aspectos que asseguram verossimilhança e acentuam reconhecimentos entre as classes sociais por ele representadas.

3 Segundo Goldstein (2003), o escritor nunca se definiu "antropólogo ou sociólogo", mas sempre o foi, mesmo sem querer ou saber. Considerado o livro preferido do autor, Tenda dos Milagres é seu $16^{\circ}$ romance, fundamentado em fatos históricos e traduzido para o alemão, espanhol, francês, húngaro, inglês, italiano. Trata-se de uma narrativa "paradigmática", em razão do cunho sociológico que a perpassa, sobretudo por expor as lutas dos subalternos contra os preconceitos instituídos pelo poder dominante. 
Apropriando-se dessa adaptação televisiva ${ }^{4}$ para pensar interfaces da memória com o universo cultural, este texto apresenta fragmentos do corpus de análise sobre o jornal mencionado e falas dos personagens. Com isso, temos a intenção de demonstrar que a ficção instiga reflexões e informa a sociedade sobre o papel histórico da imprensa nos movimentos populares.

\section{A construção da memória nos fluxos ficcionais: um Nordeste baiano?}

Vislumbrando a concepção de memória nos termos de Le Goff (2006), encontramos a ideia de ficção televisiva enquanto registro "documental, escrito, ilustrado, transmitido pelo som e imagem" (LE GOFF, 2006, p. 102). Nesse sentido, a produção ficcional se apropria da realidade para engendrar um processo marcado por relações de força que marcam uma determinada trajetória histórica. Portanto, não se trata de produções que buscam retratar apenas o passado, desvinculado dos dias de hoje, mas que estabelecem nexos e conexões do que ocorreu com a conjuntura presente. Desse raciocínio, emerge a possibilidade de que as imagens do cinema e da ficção em geral se coloquem como espaços de tessitura da memória e da história de uma época. Pollak (2000) defende que a narrativa audiovisual produz memória, porque essa categoria envolve uma operação coletiva de acontecimentos e interpretações que se pretende salvaguardar, a fim de reforçar, de uma maneira ou de outra, sentimentos de pertencimento e fronteiras sociais. Assim, falar de memória na sociedade via ficção implica analisar como um lugar ou um povo se define e se situa coletivamente em tempos diversos para inscrever sua história.

O conceito de memória não pode ser formulado de maneira unívoca e redutora, uma vez que é inacabado e se mostra em permanente

4 Na categoria "adaptação", segundo Nagamini (2004), estão implícitas as concepções de versão, inspiração, recriação, reatualização, aproveitamento temático, referência à obra, que resultam sempre num trabalho independente daquele que o originou. Nesse sentido, os possíveis diálogos entre a linguagem literária e a televisiva são entendidos neste texto como favoráveis à reconstituição da época retratada. Assim, não nos interessamos aqui em classificar estilo narrativo, apontar analogias, conjunções ou disjunções, mas destacar o caráter de conscientização fomentado pela minissérie. 
construção no espaço social, devido à polissemia que o constitui. Sob esse prisma, não se trata de desconsiderar as contribuições teóricas que primeiro traçaram o percurso de análise dessa categoria, mas de entendê-la na sua natureza de mobilidade, dadas as circunstâncias que fragmentam as memórias na vida contemporânea e a fluidez dos relatos. No final do século XX, Maurice Halbwachs a definiu como campo de investigação, buscando analisar como a coesão social se constrói a partir dos laços coletivos. Pelos quadros sociais de memória Halbwachs identificou unificação entre grupos familiares, religiosos, de classe. Entretanto, hoje essas relações sofrem intensas mudanças, então como se pensar em coesão? Mas quando discutiu as memórias coletivas, o teórico admitiu que há tantas memórias quanto os grupos que existem, o que já seria o prenúncio de uma ideia de multiplicidade em torno do conceito.

Pierre Nora é outro nome importante nessa discussão conceitual. Segundo ele, há lugares de memória que cumprem a função de transmitir valores, garantindo que a identidade nacional ou regional seja preservada. Esses lugares têm a função de contar histórias para que elas não se percam no tempo. No entendimento de Gondar (2005), Nora acenou com a possibilidade de tornar a concepção de memória social uma acepção de cunho transversal, uma vez que atravessa vários campos do conhecimento humano e diferentes saberes, não sendo relevante apenas para historiadores. É uma categoria em movimento, aberta a ser recriada, para além das definições estanques e lineares. "O conceito de memória, produzido no presente, é uma maneira de pensar o passado em função do futuro que se almeja" (GONDAR, 2005, p. 17). Trazendo esse pensamento para a nossa reflexão, de que modo Tenda dos Milagres poderia contar esse passado delineando aportes para se pensar o futuro? Argumenta a autora que nenhum documento jamais é inócuo: ele é sempre derivado de uma montagem específica de quem o produziu, como também da sociedade que tem acesso a ele. Nesse sentido, cada narrativa nos diz algo se a interrogarmos, se buscarmos sentido em seus ditos. Assim, a memória é acionada em 
razão de intencionalidades. O que Tenda dos Milagres pode nos dizer?

De acordo com tais posicionamentos, como a obra amadiana poderia ser útil para representar a memória nordestina? A Bahia poderia ser um ícone do Nordeste, segundo a retórica do escritor?

Jorge Amado, no entender de Albuquerque Júnior (2011), utiliza a ficção para "caracterizar o povo brasileiro, sua verdade interna, sua essência; preocupa-se em fazer o país enxergar o seu povo com seus suores, cantigas, macumbas, doenças, lutas, misérias, malandragens, captando as suas singularidades" (ALBUQUERQUE JÚNIOR, 2011, p. 239). Com uma narrativa inspirada no marxismo, a minissérie dá ênfase a um confronto maniqueísta entre as forças do bem (aludindo ao misticismo religioso de Archanjo e seus amigos) e do mal (representadas pela figura da polícia, através de Pedrito Gordo, e dos intelectuais, especialmente o médico Nilo Argolo com suas atitudes racistas). Entretanto, como esclarece o autor, quando se toma o Nordeste como tema de trabalho, existem nas abordagens imagens e enunciados frutos de várias estratégias de discursos que se cruzaram, de convenções que foram dadas, de uma ordenação de pensamentos consagrada historicamente. São, dessa forma, linguagens que reafirmam tipos e estereótipos construídos como essenciais: a seca, a pobreza, a desigualdade, a desesperança como signos da região, que por sua vez originam personagens que vencem seus desafios, mas que estão associados a figuras milagrosas. Temos a imagem de Xangô, atrelada à força de Pedro Archanjo, para quem a transferência de poder torna-se o único caminho para a superação das injustiças. Todavia, quando se reporta ao Nordeste, essa fragilidade humana sobressai e é como se fosse sempre insuficiente para combater o mal, necessitando por isso do arquétipo da coragem que permeia a divindade, de uma entidade mística para lhe salvar das atrocidades do mundo. "Nos discursos dos intelectuais da esquerda, como Jorge Amado, os mitos do Nordeste vão ser tomados a partir da dicotomia: civilização versus barbárie. Para esses discursos, o Nordeste sempre será mostrado como território de revolta" (ALBUQUERQUE JÚNIOR, 2011, p. 219). 
A importância da ancestralidade discutida pela minissérie, através da relação mágica de Pedro Archanjo com seu orixá, na verdade evoca não apenas elementos da memória afetiva do personagem, como também se mostra uma parábola para disseminar experiências factuais do período histórico retratado. A referência ao orixá Xangô tem uma mitologia própria, pois este é saudado nos terreiros como um rei. Suas insígnias são nobres: a coroa, o machado e o trono remetem ao seu poder, que é invocado na minissérie para aludir à luta contra o preconceito racial e a favor da liberdade de crenças, que seria empreendida pela liderança de Pedro Archanjo. Segundo a mitologia africana, o orixá teria sido um bravo guerreiro, sendo divinizado como herói após a sua morte numa batalha na qual defendia seu povo. A cólera conduz seu machado de duas faces para o enfrentamento dos inimigos, tornando-se o guardião das esperanças. Por essas razões, é venerado no Brasil como patrono do candomblé e representante da justiça social.

O desejo de preservar a memória está latente na problematização/ contextualização da obra. Pedro Archanjo foi inspirado na junção de dois ativistas políticos do mundo real: o escritor baiano Manuel Querino (abolicionista) e o Obá Miguel Santana (Babalorixá), defensores importantes da causa da liberdade religiosa na Bahia. O médico e antropólogo Nina Rodrigues, por sua vez, deu origem a Nilo Argolo (Oswaldo Loureiro), que se rebela contra as ideias vanguardistas do protagonista. Na narrativa, o caráter não fictício que perpassa fatos e personagens se dilui entre as criações do imaginário, permitindo a reconstituição histórica. Nesse sentido, Tenda dos Milagres reúne elementos biográficos, à medida que se entrelaça com o contexto da década de 1930, reproduzindo uma correlação perceptível nos diálogos, nos cenários, nos figurinos, nas ambientações dos capítulos. Essa problematização possível do gênero ficcional, segundo Lopes (2004), articula-se às ideias de mobilidade discursiva e plasticidade, pois pensamentos, imagens, símbolos, significados circulam por meio das narrativas ficcionais funcionando como chave de interpretação de 
processos identitários e abordagens sócio-histórico-culturais.

Na década retratada, a cultura do povo, os costumes, as tradições místico-religiosas são vistas como meios de intervenção da realidade, a religiosidade se misturando ao ativismo social como forma de enfrentamento das injustiças, dos preconceitos e da discriminação de crença religiosa. Tais forças populares se agregam e passam a constituir indícios da identidade regional, simbolizando a construção identitária como resultante da luta contra a exploração, a discriminação, o racismo. O Nordeste torna-se, no contexto baiano, um espaço-pretexto para homogeneizar as singularidades, promover generalidades. Tanto que muitos leitores ainda associam a região à espacialidade baiana, justamente pela descrição dos romances de Jorge Amado, que trazem a atmosfera mágica da superação das adversidades, da sensualidade das mulheres, das sociabilidades afetivas, sobretudo impulsionadas pelas imagens míticas do candomblé. Emerge, então, o misticismo como memória popular da luta pela liberdade social, que permanece viva no imaginário do público: a figura de Pedro Archanjo surge análoga a um herói da mestiçagem, defensor da religiosidade de seu povo. "São histórias que pretendem resumir coletividades, que pretendem ser emblemas para a memória de grupos ou classes. Com, isso Amado imprime ao regional uma dimensão universal, restaurando a face lírica da região" (ALBUQUERQUE JÚNIOR, 2011, p. 234).

\section{Nos fragmentos da minissérie, uma memória da história?}

Instaurando uma referencialidade realista, esse produto da ficção parte de traços históricos, fazendo emergir novos sentidos, que por sua vez inventam e reconstroem uma nova realidade pelos olhos dos espectadores. Quando narra a violência física e simbólica sofrida pelos negros e os conflitos religiosos, coloca em perspectiva a questão das identidades e das identificações em torno de um pertencimento social e religioso, fomentando as bases para uma reflexão na esfera pública. 
Do ponto de vista narrativo, Tenda dos Milagres visibiliza o letramento como possibilidade dessa transformação, apresentando um valioso investimento na escritura enquanto registro histórico dos indivíduos e preservação da memória das lutas culturais populares pela cidadania e a superação do racismo. A materialização dessa dinâmica, que mobiliza a solidariedade popular, ocorre através do personagem Pedro Archanjo. No diálogo com sua mãe de santo, que ora transcrevemos, esse foco se notabiliza:

Majé Bassã: Tu foi agraciado com um dom divino, Archanjo!
Do povo daqui, tu é um dos poucos que pode fazer alguma
coisa pela tua raça (...) Xangô tá falando, tá te ordenando
"tudo ver, tudo saber, tudo escrever". Tu foi escolhido para
ser Ojuobá, os "olhos de xangô"! Tu vai ser a luz do teu povo,
nossos olhos de ver, e nossa boca de falar, tu vai ser nossa
coragem e nosso entendimento. Tu vai dizer do nosso amanhã.
É por isso, meu filho, que tu pensa tanto em escrever, vive
anotando as coisas do teu povo, é porque xangô te escolheu.
Pode começar a cumprir tua obrigação, que já tá na hora!

O acréscimo do imaginário se mistura, portanto, a enunciações do mundo real, constituindo uma estratégia que confere verossimilhança às situações vividas pelos personagens, que reproduzem a história vivida pelo país naquele contexto. No capítulo 23, a jornalista Ana Mercedes lê palavras de Archanjo supostamente publicadas no jornal $A$ Voz da Raça: "A liberdade e o respeito às religiões católica e protestante devem ser assegurados também aos cultos afro-brasileiros. Seus adeptos devem ter sua crença respeitada dignamente quanto os milhares de cidadãos das outras correntes religiosas."

No Capítulo 33, Nilo Argolo lê a manchete: O monstro Argolo ensandeceu. "Alguém tem que dar um ponto final nessa história de imprensa negra! Deve haver alguma lei que proíba a circulação dessa nojeira! (...) Mas eu sei me defender dessa corja!". Publica então um artigo, que se inicia pelo seguinte texto: "A casta negra é atraso; a branca é progresso e evolução. Os mestiços são afetados pela demência".

Na mesma edição do jornal, Pedro Archanjo reitera seu discurso, atiçando ainda mais a ira do seu opositor: "Os sangues na Bahia não têm cor e se misturam de cima para baixo na hierarquia social. Portanto, 0 
preconceito de cor é uma ideia fora de lugar. Não são poucos nem fracos os que formam os grupos racistas: acadêmicos, autoridades do governo, proprietários rurais, médicos, intelectuais de diversos saberes. Porém, racismo é uma bandeira que devemos combater! Todos nós temos uma história que não tem cor! Nossos jovens, intelectuais ou não, devem preservar nossa memória, nossas raízes e não se envergonhar delas!". Com esse teor combativo, o periódico denuncia as questões atreladas ao preconceito racial e à liberdade de culto religioso. No contexto da época, esse jornal representou a cultura de resistência dos negros e mestiços, combatendo a premissa de que esses seriam obstáculo ao processo civilizatório brasileiro. Zaluar (1998) defende a cultura da imprensa alternativa como uma dinâmica de interação social contínua em que os símbolos coletivos e seus significados são reinterpretados. "Desse modo, o povo em união transmite seus valores fundados historicamente para as gerações futuras" (ZALUAR, 1998, p.119).

Contudo, a preocupação com a memória social na minissérie não permeia apenas as páginas do jornal, mas também emerge na representação do terreiro de Majé Bassã, palco de violência e perseguição das autoridades policiais. Vinagre Silva (2007) nos esclarece que os terreiros são espaços históricos que guardam as tradições e simbolizam a cultura oral dos afrodescendentes, configurando nichos de sociabilidade para o enfrentamento do preconceito e lugares de preservação da memória sociocultural. A geografia dos terreiros expressa, pois, uma ocupação sociopolítica, uma vez que os Ilês são casas religiosas, mas também espaços étnicos, de moradia, de acolhimento, de prestação de serviços assistenciais à coletividade. Para a autora, as relações afetivas de parentesco - consanguíneo e religioso-, articuladas às relações de gênero, interétnicas e de classe, modelam e regulam relações, não só religiosas, mas econômicas, socioculturais e ético-políticas. Desse modo, "as práticas são ressignificadas cotidianamente nesses territórios, formando elos entre o presente e o passado, entre o mundo contemporâneo real e o mundo mítico, elos entre o território religioso dos terreiros e a vida social" (VINAGRE SILVA, 2007, p. 5). 
A autora assinala que esses espaços valorizam e preservam a identidade cultural dos filhos de santo, uma vez que produzem a reafirmação étnica, incorporando indivíduos discriminados socialmente em outros espaços: negros/não-negros, homens/mulheres/crianças, indivíduos de diferentes orientações sexuais e pertencentes a distintas classes, inclusive os portadores de deficiência e de comprometimento mental, que não aceitos em outras práticas religiosas. "No terreiro de candomblé, os segmentos subalternizados da sociedade podem experimentar a possibilidade de ascensão social, e de desenvolvimento de uma nova sociabilidade, metamorfoseando seus lugares de desvantagem social com posições de prestígio na hierarquia religiosa" (VINAGRE SILVA, 2007, p. 6).

Dessa forma, segundo Albuquerque (2012), o candomblé preserva a herança africana no Brasil, que é repassada pela oralidade como fator de preservação da memória social com suas crenças e tradições. No fim do século XIX, o conhecimento dos velhos africanos, transmitido oralmente de geração a geração, já incorporara influências pagãs (formas de "feitiçaria") e cristãs (principalmente devoções) provindas da Península Ibérica, especialmente de Portugal. Assim, os terreiros funcionam enquanto tentativa de reafricanização das práticas simbólicas, locais onde se pratica o aprendizado dos idiomas, mantendo a memória da tradição e a preservação do patrimônio cultural das religiões de matrizes africanas, além de significarem adesão e pertencimento à crença dos ancestrais e à etnicidade afro.

Nesses ambientes religiosos, as mulheres, principalmente as negras, conforme ilustra a Mãe Majé Bassã, ocupam lugar de respeito na hierarquia, ao contrário do que se verifica em outras religiões. O terreiro ainda se constitui num espaço de permanência e resistência histórica dos afrodescendentes. Nesta territorialidade a matriz africana se perpetua a partir dos rituais, dos costumes, da culinária, da musicalidade dos atabaques, que mantêm viva a memória das crenças afro-brasileiras. A relação de Archanjo com sua mãe de santo, por sua vez, evoca um sentimento de reverência que é explicado com propriedade por Negrão 
(2009): "O candomblé é uma religião de memória, irmandade, de afetos, que valoriza os indivíduos, reforça suas identidades, integrando-os em uma família mística, que Ihes proporciona aconchego, amor e proteção filial" (NEGRÃO, 2009, p. 268).

Assim, Majé Bassã representa o afeto e a autoridade máxima nas questões da tradição religiosa. A ela é atribuído o arquétipo de "conhecimento" disseminador de memória, denominado de axé, bem como a missão de cuidar da vida de seus discípulos; conhecer seus amores, dramas e dificuldades; guiá-los nas mais diversas circunstâncias, trabalhando para curar males físicos e espirituais da comunidade religiosa com sabedoria e dedicação, orientando, enfim, as trajetórias de sua vasta "família de santos", que irão repassar adiante seus ensinamentos.

Medeiros (2012) assinala que não apenas os discursos, mas os figurinos e a reconstituição da época fazem da ficção veículos de construção da memória. As roupas e os objetos mobilizados são elementos detentores de "um impressionante poder intangível, de absorção de significados simbólicos, nos quais as memórias e as relações sociais são corporificadas, ganhando existência própria" (MEDEIROS, 2012, p. 158). As identidades, nesse processo, são transferidas para esses objetos, que passam a guardar histórias e contextos de determinadas épocas, provocando posterior reconhecimento entre os espectadores.

Essa problematização de símbolos da sociedade e das tradições culturais no gênero ficcional, segundo Lopes (2004), articula-se às ideias de mobilidade discursiva e plasticidade, pois pensamentos, imagens, símbolos, significados circulam por meio das narrativas ficcionais podendo tais questões funcionar como chave de interpretação de processos identitários e abordagens sócio-histórico-culturais. Nesse sentido, a lógica que move a ficção televisiva dá espaço a representações promovendo reflexões junto à esfera coletiva, cuja ressonância alimenta as discussões mostradas na tela da TV.

Nessa ótica, a ficção televisiva, por suas características de 
hibridismo e de preocupação com a identidade nacional, torna-se veículo de interculturalidade, podendo ativar a competência cultural, a socialização das experiências criativas e o reconhecimento das lutas populares, das diferenças e das alteridades (LOPES, 2004). Permite 0 conhecimento dos que os outros fazem, como pensam, como manifestam sua fé, quais seus pertencimentos étnicos, quais as expectativas e conflitos de diferentes gerações em diversos tempos históricos.

Ressaltando o poder de ressonância da ficção na esfera da audiência, a autora enfatiza que esse gênero adquire valor estratégico na criação e consolidação de novas identidades culturais compartilhadas, consistindo numa narrativa popular sobre a nação. Torna-se, assim, um lugar privilegiado na TV de onde se anuncia uma nação representada e não só "imaginada". "Histórias narradas pela televisão são, antes de tudo, importantes por seu significado cultural, oferecendo material precioso para se entender a cultura e a sociedade de que é expressão" (LOPES, 2004, p. 125). Na mesma direção, Silverstone (2002) reitera que as tramas ficcionais são nossa cultura e reflexo de nossa sociedade, "gostemos disso ou não, expressando as consistências e contradições da fantasia (...) oferecendo textos para que nós, suas audiências, nos posicionemos, nos identifiquemos" (SILVERSTONE, 2002, p. 82).

Nesse sentido, a verossimilhança das tramas é tecida no interior da narrativa, o que permite o fortalecimento das raízes do gênero ficcional em meio à sociedade e à cultura que o produzem. Corroborando essa assertiva, Bulhões (2009) postula: "A ficção não é um invólucro impenetrável, uma cápsula suspensa na imaterialidade: só pode transfigurar o real por tê-lo conhecido, por isso o subverte" (BULHÕES, 2009, p. 22).

Na ótica de Martín-Barbero (2004), a fruição estética do gênero ficcional apresenta ainda um aspecto significativo para além da intenção de verdade, da mobilização da memória e do imaginário do público, uma vez que por seu intermédio entendemos ainda as tradições específicas de um povo e as culturas mestiças dos países que são retratados. Por isso, a televisão se configura hoje como "o dispositivo mais 
sofisticado de modelagem e formação dos gostos populares, numa das mediações mais expressivas das matrizes narrativas do mundo cultural popular" (MARTÍN-BARBERO, 2004, p. 24). Exerce, dessa forma, papel estratégico na cultura cotidiana das maiorias, na transformação de suas sensibilidades, na construção de suas identidades. Nesse sentido, formata uma imagem estratégica de determinados universos do mundo real, possibilitando o reconhecimento entre a audiência, notabilizando "um modo comprometido" de ver, escutar ou ler uma dada historicidade.

$\mathrm{Na}$ esfera da identificação e da visibilidade, os gêneros ficcionais ainda se mostram em permanente estado de fluxo e redefinição, despertando novas inteligibilidades, mesclando particularidades, conformando novas sínteses sociais, restituindo e atualizando velhas histórias que são caras à cultura e à memória populares. Segundo Lopes, Borelli e Resende (2002), esses gêneros compreendem mitologias, reposições arquetípicas, matrizes culturais, estruturas narrativas que respondem pela possibilidade de elaboração de grandes totalidades do imaginário coletivo, "partilhando, como universalidades das construções imaginativas, do referencial de qualquer leitor, de qualquer receptor. São assim pontos de intercessão nas relações entre cultura popular, erudita e de massa" (LOPES; BORELLI; RESENDE, 2002, p. 254).

Hall (2005) assegura que a polissemia da TV dissemina uma pluralidade de ideias que podem salvaguardar uma dada historicidade. Motter (2004), em pensamento similar, destaca que os romances, as histórias de amor, correm em paralelo com o desenvolvimento de temáticas sociais, que são pinçadas do cotidiano, como também "questões embrionárias e nebulosas, marginalizadas como tabus, objetos de proscrição e silêncio, ou difusas, como mitos nascentes, objetos de temor, enlevação, encantamento e perplexidade". (MOTTER, 2004, p. 259).

De acordo com Gordillo (2010), a ficção desempenha importantes funções, sobretudo no sentido filogenético: reproduz desdobramentos e hibridações que suscitam reflexões, discussões e ressonâncias. Além disso, ainda permite: fabulização, numa tentativa de atrair as pessoas 
para outros contextos, mediante a ação de personagens, tempos e espaços (por modos de representação popular); socializadora, ao unir grupos sociais em torno de temáticas comuns, gerando adesões, gostos e preferências; função identitária, pois surge como intérprete da vida social, compartilhando os significados coletivos e expressando as mutações culturais; disseminadora de modelos, ao organizar situações e personagens familiares, convertendo os estereótipos em sugestões de comportamento social; função formativa, pois alguns relatos expõem mensagens educativas.

No capítulo 13, o preconceito com a mestiçagem é explícito, pois Pedro Archanjo comenta indignado com sua amiga Rosa de Oxalá (Dhu Moraes), que Nilo Argolo publicou infâmias na sua obra mais recente, intitulada "A degenerescência psíquica e mental dos povos mestiços". Pedro Archanjo [Exaltado, após a leitura]: - "Rosa, nós não somos degenerados em promiscuidade imunda, animais, ou pior, 'criminosos', como escreveu o professor de medicina! Um doutor que deveria se envergonhar desses insultos... Mas é mentira, Rosa, é calúnia desse sabe tudo que não sabe nada!"

Em retaliação a esse discurso, Pedro Archanjo sistematiza o seu primeiro livro, "A vida Popular na Bahia", iniciando a obra com uma frase emblemática, que dita o tom que inspirou a publicação: "É mestiça a face do povo brasileiro e é mestiça a sua cultura". Nesse livro, o protagonista repete um pensamento do poeta Manoel Querino, que inspirou o personagem: "O Brasil possui duas grandezas reais: a uberdade do solo e o talento do mestiço". O jornal A Voz da Raça publica um manifesto de apoio ao livro de Archanjo, convocando os leitores à adesão à causa.

O delegado Pedrito Gordo (Claúdio Mamberti) também expressava publicamente seu pensamento racista nas entrevistas que concedia ao jornal: "Não sou eu. São os mestres da Bahia que afirmam a alta periculosidade da negralhada. Eu apenas trato de cortar o mal pela raiz evitando que ele se propague! Cadeia neles!" Na verdade, as religiões de origem africana no Brasil enfrentaram discriminação e a repressão 
policial embasada na lei, que perdurou até a década de 1970, do século $X X$, quando então a violência física contra os adeptos foi refreada, resultado de uma luta vitoriosa dos integrantes das religiões afrobrasileiras pela inclusão constitucional (ISAIA; MANOEL, 2012).

Por muitas décadas, foram estigmatizados como grupos de charlatães ou feiticeiros, tendo as suas práticas de religiosidade colocadas no patamar de bruxaria e à margem das religiões oficiais. Na concepção de Goffman (1988), o estigma é a situação do indivíduo que está inabilitado para a aceitação social plena. Trata-se de um termo profundamente depreciativo, que nega a possibilidade de relações e se refere a atributos. Os preconceitos derivam dos estigmas e se atravessam nas diferentes esferas sociais. Na visão do autor, o preconceito se contrapõe às qualidades de caráter, como lealdade, compromisso, honestidade, propósitos que (re)afirmam valores atemporais e regras éticas, produzindo espaço para a exclusão social, a violência e a discriminação. Os estigmas tribais de raça, nação e religião podem ser transmitidos através de uma linhagem e contaminar por igual todos os membros de uma mesma família.

Na minissérie, o candomblé é visto como "magia dos negros" pelas autoridades policiais e acadêmicas, o que os torna discriminados aos olhos da sociedade. "Nos processos de socialização e nas interações sociais e religiosas, surgem, da parte dos excluídos, sentimentos de medo, vergonha, humilhação, impureza, contaminação" (GOFFMAN, 1988 , p. 14), o que gera afastamento social.

No entanto, Capelato (2007) adverte que existem imagens padrões, identificadas como ícones "canônicos", ligadas a conceitoschave cristalizados na vida social. Então, é preciso atenção para que tais imagens, atuando como referências inconscientes, não produzam efeitos subliminares de identificação coletiva, do ponto de vista pejorativo ou negativo. Em outras palavras, as imagens mostradas na minissérie podem ser entendidas enquanto valorização das tradições e lutas dos negros contra o racismo, mas, por outro lado, também podem alimentar estereótipos que associam os negros somente à vitimização, 
esquecendo-se de realçar suas qualidades resilientes. Todavia, esse debate, que atrela a África e seus descendentes a adjetivos inferiores no contexto histórico, é oportuno e relevante, porém ultrapassa os limites e as pretensões deste artigo.

Torna-se válido ressaltar que somente em 1985, período da exibição da minissérie, as mais importantes Ialorixás de Salvador, Mãe Stella do Axé Opô Afonjá, Mãe Menininha do Gantois e Mãe Olga do Alaqueto, divulgaram na imprensa nacional, com efetivo apoio do Movimento Negro da Bahia e dos Grupos de Direitos Humanos, um documento pelo qual afirmavam que o candomblé não é uma manifestação folclórica, uma seita, ou uma religião selvagem e primitiva. Esse pronunciamento a favor da valorização do negro e de suas crenças, que também ocorria em nível internacional, se refletiu em Salvador, o que resultou numa série de medidas oficiais visando à preservação da cultura e da memória africanas em todo o país (NEGRÃO, 2009). Nesses termos, a minissérie contribuiu para visibilizar tais questões no espaço social.

A articulação da memória individual e da memória coletiva tratase, conforme explica Gondar (2005), de uma intervenção cognitiva sistemática, pois ao ligar imagens e fatos com acontecimentos do passado, desenvolvemos três operações: ação intelectual que associa as lembranças por atribuição de significados; ação de rememoração, que liga e identifica experiências passadas a fatos presentes; e ação de compartilhamento, à medida que discutimos e repassamos aos outros fatos vividos, cujas similaridades repetem situações conhecidas. Nesse raciocínio, é o tempo que proporciona o sentido das memórias dos grupos sociais. Cada realidade fornece singularidades simbólicas, discursivas e relacionais que ativam a compreensão de contextos e situações históricas. A memória social, portanto, se inscreve num processo de circulação e ressignificação que ordena e classifica os fatos segundo critérios sociais de mediação de significados. Assim, a memória torna-se elemento essencial da construção da identidade de um grupo, do sentimento de continuidade e coerência que reconstrói 
uma coletividade e escreve sua história ao longo das transformações vividas que permitirão ativação das lembranças e reconhecimento.

\section{Considerações Finais}

A pesquisa apontou que a teledramaturgia pode funcionar como espaço de interlocução para importantes problematizações, expressando as mudanças, tensões, contradições e singularidades próprias de um país multicultural. Apresentando elos com a obra literária que a inspirou, Tenda dos Milagres revela sua intertextualidade, discutindo a prática do candomblé em meio às dificuldades privadas das relações humanas e familiares, atrelando-se aos fatos amorosos, afetivos e políticos do contexto retratado, a exemplo das situações que apontam o preconceito e a perseguição aos negros, noticiadas pelo jornal $A$ Voz da Raça e disseminadas nos livros de Pedro Archanjo.

Compreendida por esse ângulo, a produção visibiliza as referências históricas e humanas dos agentes sociais que escreveram o passado nordestino, com suas expectativas e lutas, a exemplo dos afrodescendentes. Em sua plasticidade e apropriações narrativas, dissemina a valorização da cultura negra e da sociabilidade baiana, instigando uma racionalidade sensível para o universo simbólico do candomblé, ao passo em que forja uma reflexão histórica sobre a discriminação que permeia essa prática religiosa, sobretudo quando retrata os estigmas religiosos do início do século XX.

Engendrado que foi nas entranhas da escravidão, o fenômeno do candomblé encontra-se, desde seus primórdios, ligado à inserção do negro na sociedade brasileira e a sua capacidade de resiliência. Assim, as mensagens de Tenda dos Milagres são verossímeis, transcendendo a temporalidade em que foram escritas, permitindo a circulação, apropriação e interação de novas práticas simbólicas, reelaborando os sentidos da participação popular, da ressonância da história do povo negro e nordestino, emblemático e singular no enfrentamento dos estigmas raciais que o perpassam. Conta uma história, cujos 
ecos e reivindicações permearam a trajetória do jornalismo, enquanto relevante espaço de preservação da memória social e democratização das lutas em prol da cidadania.

\section{REFERÊNCIAS}

ALBUQUERQUE, Paulo Roberto Lopes de. Os símbolos de Xangô. IN: MIELE, Neide (Org). Religiões, múltiplos territórios. João Pessoa: Editora UFPB, 2012.

ALBUQUERQUE JÚNIOR, Durval Muniz de. A invenção do Nordeste e outras artes. 5a ed. São Paulo: Cortez, 2011.

BULHÕES, Marcelo. A ficção nas mídias: um curso sobre a narrativa nos meios audiovisuais. São Paulo: Ática, 2009.

CAPELATO, Maria Helena et al. História e cinema: dimensões históricas do audiovisual. São Paulo: Alameda, 2007.

CORREIA, João Carlos. De que modo a noção de espaço público altera-se e afeta o jornalismo cultural? In: BRASIL, André (Org). Cultura em fluxo: novas mediações em rede. Belo Horizonte: Editora PucMinas, 2004.

CUCHE, Denys. A noção de cultura nas ciências sociais. Tradução: Viviane Ribeiro. $2^{a}$ ed. Bauru: EDUSC, 2002.

GOFFMAN, Erving. Estigma: notas sobre a manipulação da identidade deteriorada. Rio de Janeiro: Guanabara, 1988.

GOLDSTEIN, Ilana. O Brasil best seller de Jorge Amado: literatura e identidade nacional. São Paulo: Editora Senac, 2003.

GONDAR, Jô. Quatro proposições sobre memória social. In: GONDAR, Jô; DODEBEI, Vera (Orgs). O que é memória social? Rio de Janeiro: Contra Capa Livraria, 2005.

GORDILLO, Inmaculada. Manual de narrativa televisiva. Madrid: Editorial Sintesis, 2010.

HALL, Stuart. A identidade cultural na pós-modernidade. Rio de Janeiro: DP\&A, 2005.

ISAIA, Artur Cesar; MANOEL, Ivan Aparecido (orgs.). Espiritismo \& religiões afro-brasileiras: história e ciências sociais. São Paulo: Uniesp, 2012.

LE GOFF, Jacques. História e memória. Campinas: UNICAMP, 2006.

LOPES, Maria Immacolata Vassalo de; BORELLI, Silvia Helena Simões; RESENDE, Vera da Rocha. Vivendo com a telenovela. São Paulo: Summus Editorial, 2002. 
LOPES, Maria Immacolata Vassalo de. Para uma revisão das identidades coletivas em tempos de globalização. In: LOPES, Maria Immacolata Vassalo de (Org). Telenovela: internacionalização e interculturalidade. São Paulo: Edições Loyola, 2004.

MARTÍN-BARBERO, Jesús. Viagens da telenovela: dos muitos modos de viajar em, por, desde e com a telenovela. In: LOPES, Maria Immacolata Vassalo de (Org). Telenovela: internacionalização e interculturalidade. São Paulo: Edições Loyola, 2004.

MEDEIROS, Cléryston Raffael Wanderley de. Memória e esquecimento na pós modernidade. In: BURITI, Iranilson (Org). Identidades e sensibilidades: 0 cinema como espaço de leituras. Campina Grande: EDUEPB, 2012.

MOTTER, Maria Lourdes. Mecanismos de renovação do gênero telenovela: empréstimos e doações. In: LOPES, Maria Immacolata Vassalo de (Org). Telenovela: internacionalização e interculturalidade. São Paulo: Edições Loyola, 2004.

NAGAMINI, Eliana. Literatura, televisão, escola: estratégias para leitura de adaptações. São Paulo: Cortez Editora, 2004.

NEGRÃO, Lísias Nogueira (Org). Novas tramas do sagrado: trajetórias e multiplicidades. São Paulo: Editora FAPESP, 2009.

POLLAK, Michael. Memória e identidade social. Estudos Históricos. São Paulo: PUC, 2000.

SILVERSTONE, Roger. Por que estudar a mídia? São Paulo: Edições Loyola, 2002.

VINAGRE SILVA, Marlise. O exercício do poder feminino na tradição étnico-religiosa iorubá no Brasil: uma estratégia para concretizar direitos em uma sociedade globalizada e desigual. CBASS. Artigo. Foz Do Iguaçu, 2007.

ZALUAR, Alba. Teoria e prática do trabalho de campo. In: CARDOSO, Ruth. A aventura antropológica. Rio de Janeiro: Paz e Terra, 1998. 